\title{
Tourism and preventive measures taken in transmission of COVID-19 in Galle District, Sri Lanka
}

\author{
Kanakka Hewage Priyantha Jeewarathne', Wenura Kumara Singarachchi ${ }^{1}$, Bhadra Chandanie \\ Mallawaarachchi ${ }^{1}$, Don Chinthaka Atukorala ${ }^{1}$, Kanchitha Thathsara Samararathna ${ }^{1}$, Nalin Prasanna \\ Wijesekara ${ }^{1}$, Dinesh Gunarathna ${ }^{2}$, Indeewarie Eranga Gunaratna ${ }^{1^{*}}$ \\ ${ }^{1}$ Office of the Regional Director of Health Services, Galle, Sri Lanka; ${ }^{2}$ Smallholder Tea and Rubber \\ Revitalization Project, Ministry of Plantation Industries, Colombo, Sri Lanka
}

"Correspondence: indeewariegunaratna@gmail.com https://orcid.org/0000-0001-5949-244X

DOI: https://doi.org/10.4038/jccpsl.v26i5.8321

Received on 8 May 2020

Accepted on 5 June 2020

\section{Summary}

Tourism is the third profitable foreign exchange earning industry globally as well as in Sri Lanka contributing to $16 \%$ of foreign exchange during 2018 (1). The five top tourist traffic source markets to Sri Lanka are India, United Kingdom, China, Germany and Australia (2). Out of all arrivals, 96\% enter the country through Bandaranaike International Airport (BIA) (1).

Sri Lanka is ranked the top tourist destination in the world by the famous travel website 'Lonely Planet' in 2019 (3). Galle being the capital of Southern Sri Lanka is a heritage city with many tourist attractions with its Portuguese Architect (4). Emergence of COVID-19 reported on 31 December 2019 from Wuhan, Hubei Province, China expansively affected the international travel and trade. This narrative report highlights the response made to mitigate the outbreak and challenges faced by public health authorities during COVID-19 pandemic in Galle District- the most populated tourist destination in Sri Lanka.

\section{Public health response and its impact}

The relevance of tourism to COVID-19 in Sri Lanka

Sri Lanka reported the first case of COVID-19 on 27 January 2020. It was a traveller from Wuhan, China (5). First COVID-19 local case was reported on 11 March 2020 followed by the second local case immediately afterwards (6). Both were tour guides in occupation. All three cases had travelled in most districts including Galle that alarmed Sri Lanka on the risk of transmission through tourists.

Nearly 500,000 tourist arrivals had been reported in Sri Lanka up to 18 March 2020. Majority of them were Europeans (60\%) followed by Asians and Pacific Islanders (34\%) (7). By mid-March, China and South Korea were in the declining phase of the COVID-19 epidemic, while European countries 
(Spain, France and Germany) were reporting more than 1000 new cases per day. Italy reported more than 3000 cases per day. Nevertheless, total cases reported in India were 137 (6). Since Sri Lanka's main source destinations are among the high risk COVID-19 transmission countries, BIA was closed on 18 March 2020 (7). This ceased total tourism trafficking into the country. This led to a substantial contribution towards avoiding the virus being spread through international travellers. In concurrence, the Sri Lanka Bureau of Foreign Employment and Sri Lanka Institute of National Tourist Guide Lecturers also took many immediate measures to curb the outbreak (8).

As per the National Guidelines of the Ministry of Health, decisions were taken especially on quarantine of all foreign travellers who had entered the country from 1 February 2020 (9-10). The Epidemiology Unit of Sri Lanka shared contact details of all the immigrants identified at BIA with regional epidemiologists (REs) on a daily basis. They consolidated the district data and shared it with all relevant medical officers of health (MOHs) who acted as the administrative head, health manager and competent authority of all public health legislative enactments of Sri Lanka at regional level. The active enforcement of Quarantine Ordinance was implemented and the public health inspectors (PHIs) who are the authorized officers, traced, enlisted contacts and quarantined them as per the degree of contact. The Department of Police and the National Intelligence Bureau helped health authorities to find out untraceable contacts and offenders of the quarantine enactment.

\section{Actions taken by regional health authorities}

Under the guidance of Director General of Health Services (DGHS), many activities were implemented at district level to mitigate the outbreak of COVID19. Main aim of the whole surveillance process was to prevent community transmission, manage the outbreak within the capacity of the health system and to identify and treat COVID-19 cases early to prevent complications and death.

A total of 73 tourists have directly travelled to Galle District from BIA and were quarantined for 14 days in their accommodations (Figure 1). This also included Chinese nationals returning for employment in Sri Lanka. Fever monitoring two times a day and inquiries on symptoms of COVID-19 from every quarantined tourist were done by the relevant $\mathrm{MOH}$. None of them showed signs or symptoms of COVID-19 until on 9 March 2020, a European tourist who was quarantined for 14 days at one of the beach hotels became positive 4 days after departure. No sooner the information was received, all the first-line contact hotel staff was quarantined for 14 days (Figure 2) and tested for COVID-19 $(n=7)$. All showed negative results.

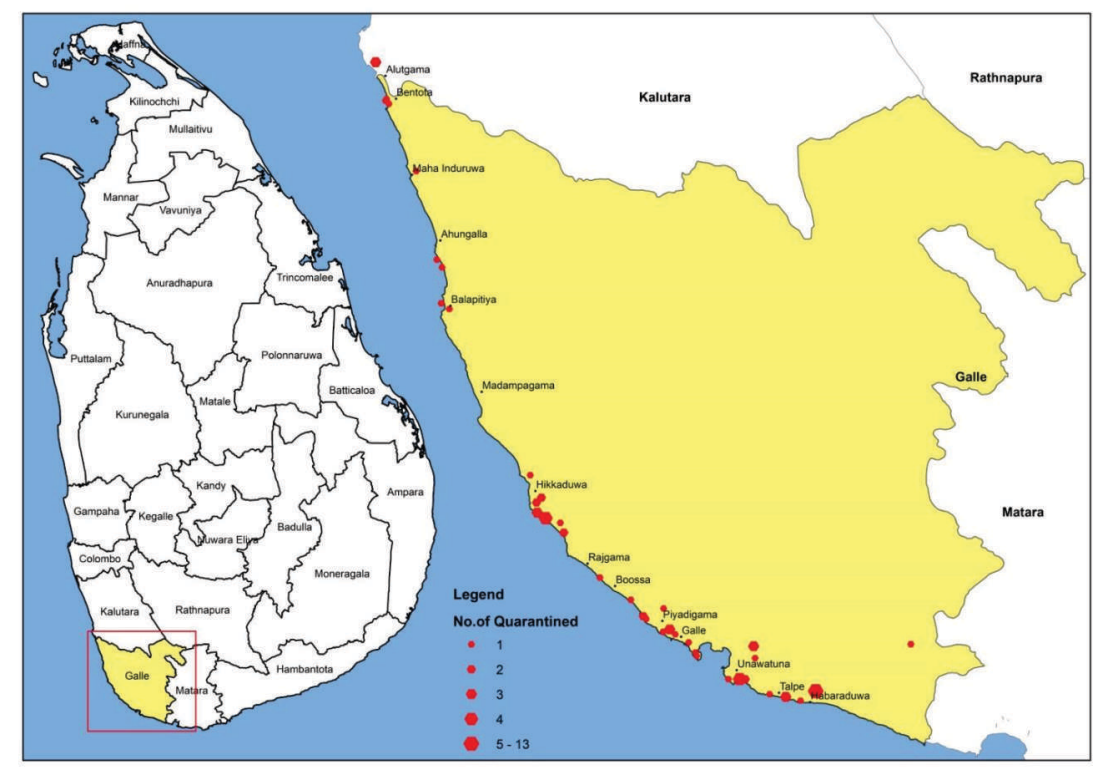

Figure 1: Distribution of tourists under quarantine in Galle District 
Altogether, only three tourists had become positive up to date in Sri Lanka and two of them had links to Galle District (Figure 2). First patient was a female tourist from Wuhan, China who became symptomatic while staying in Galle District. Prompt investigations and outbreak management was carried out by the RE and the $\mathrm{MOH}$ of the area. Detailed travel history within Sri Lanka was obtained from her and shared with other districts, facilitating the implementation of public health measures to mitigate the local spread. The second tourist ( $45^{\text {th }}$ patient) was travelling with his daughter and was identified with symptoms on the first day they arrived in Galle. Following admission to Teaching Hospital Karapitiya and testing, he was found to be positive for COVID-19. The daughter was kept in a quarantine centre under the purview of the Security Forces of Sri Lanka, while the tour guide and possible contact hotel staff $(n=8)$ were strictly quarantined at their own residence and followed-up under the supervision of $\mathrm{MOH}$. Hotel was disinfected and closed as a temporary measure and health education was given for hotel staff.

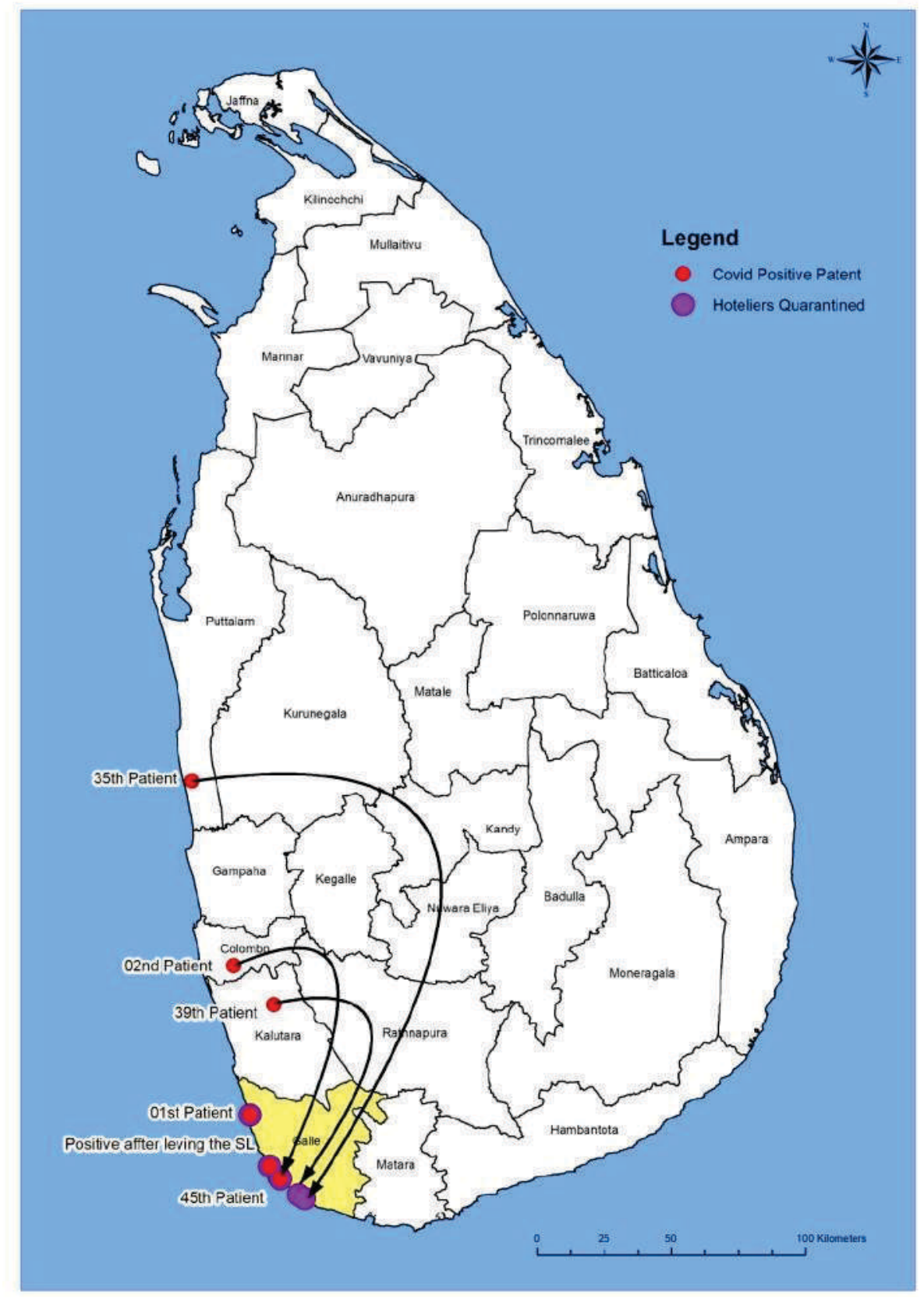

Figure 2: Distribution of positive patients induced quarantine process 
Similar measures were taken when tour guides $(n=3)$ who visited Galle District with a team of European tourists became positive for COVID-19. First local patient ( $2^{\text {nd }}$ patient), $35^{\text {th }}$ patient and $39^{\text {th }}$ patient were tour guides tested positive for COVID-19. Hotel workers with possible exposure (283 and 12 persons respectively - Figure 2) were subjected to either home quarantine or quarantine within the hotel for 14 days. Other district authorities were also informed about possible exposure of hoteliers residing in their districts. All the hotels were disinfected, temporarily closed, made aware of respiratory etiquette and monitored. Communication between the tourist sector and preventive health sector was strengthened to facilitate the implementation of preventive measures. This has been continued to date.

\section{Challenges faced}

Public health system faced many challenges during the whole process. Although the majority of hoteliers adhered to instructions provided by health authorities, some of the quarantined persons found it difficult to confine themselves to their houses. Inadequacy of space and facilities within their home for self-quarantine (extended family living in a small space, unavailability of a separate room, separate lavatories, separate utensils and facilities for fever monitoring), stigmatization by neighbours or villagers and supply of food from outside when the whole family is under quarantine are some of difficulties faced by public health authorities when implementing home-quarantine instructions. Therefore, action was taken to quarantine some of them in hotel premises. Owing to a large number of tourists occupying the hotel, health authorities found it difficult to lockdown hotels or quarantine all the staff when a foreigner or tour guide who had visited the hotel became positive. Therefore, measures were taken to lockdown separate wings of hotels, take optimal precaution to prevent cross-infection and quarantine the staff members who had the exposure. Insecurity of belongings and loved ones left in the hotel became a problem once a foreign national became positive for COVID-19. In such instances, public health authorities took action to transfer them to quarantine centres governed by security forces.
Another major challenge encountered during this period was implementing quarantine regulations on foreign nationals. It was difficult to locate foreigners due to varied travel itineraries and kept to their preplanned activities. Moreover, language barriers, antisocial behaviour of some foreigners and delays in acclimatization to instruction by the local lateral service providers (three-wheeled taxi drivers, boutique hotel owners, cashiers, etc.) posed challenges to the public health authorities. With the fullest support of security forces, all the contacts were traced and quarantined.

Neither tourists nor contacts gave rise to local transmission of the disease in Galle District. Proactive contact tracing and uninterrupted followup action prevented the spread of the disease from tourists and their associates. Curfew imposed within the district further benefited the success. Excellent coordination within the health sector (timely data sharing, daily updates on country situation, regular review meetings), teamwork and obedience and respect to speculated guidelines issued by health sector were strengths for the success within public health systems. Moreover, collaboration and strong partnerships between different partners created a solid platform to mitigate the propagation of the outbreak as well as to move forward.

In the backdrop of the whole world in a stand-still in relation to all aspects; economic, social, livelihood, religious, recreational except the mission on saving lives and preventing spread through maintaining health services and security services, Galle District is gradually exiting out of the immediate threat and moving forward as a low risk district with only one reported local case.

\section{Author Declaration}

Author contributions: All authors were involved in planning of the article and in literature search. KHPJ and IEG drafted the manuscript and all authors were involved in editing it. DG developed all the maps. IEG did the overall supervision. All authors approved the final manuscript. 


\section{References}

1. Research and International Relation Division. Annual Statistical Report. Colombo: Sri Lanka Tourism Development Authority, 2018. Available from: https://sltda.gov.lk /storage/documents/ 0cb228cd03762f638bd515fe83edd453.pdf. Accessed 1 May 2020

2. Research and International Relation Division. Monthly Tourist Arrivals Report, December. Colombo: Sri Lanka Tourism Development Authority, 2019. Available from: https:// sltda.gov. lk/monthly-tourist-arrivals-reports-2019. Accessed 1 May 2020.

3. C Adams. Lonely Planet's best in travel 2019: Sri Lanka tops list of countries to visit next year. Independent, 23 October 2018. Available from: https://www.independent .co.uk/travel/news-andadvice/lonely-planet-best-travel-2019-sri-lankagermany-zimbabwe-copenhagen-shenzhen-novisad-a8597156.html.

4. World Heritage Centre. World Heritage List. UNESCO, 1992-2020. Available from: https://whc.unesco.org/en/list/. Accessed 1 May 2020.

5. Epidemiology Unit. Novel coronavirus (2019$n$ CoV) - Situation Report, 28 January 2020. Colombo: Ministry of Health, Nutrition and Indigenous Medicine, 2020. Available from: http://epid.gov.lk/web/images /pdf/corona virus_report/sitrep-sl-eu-28-01.pdf. Accessed 25 April 2020.
6. Epidemiology Unit. Coronavirus disease 2019 (COVID-19) - Situation Report, 12 March 2020.

Colombo: Ministry of Health, Nutrition and Indigenous Medicine, 2020. Available from: http://epid.gov.lk/web /images/pdf/corona_ virus_report/sitrep-sl-en-12-03_10.pdf. Accessed 25 April 2020

7. Research and International Relation Division. Monthly Tourist Arrivals Report, March. Colombo: Sri Lanka Tourism Development Authority, 2020. Available from: https://sltda .gov.1k/monthly-tourist-arrivals-reports-2019. Accessed 1 May 2020.

8. Ada Derana Prime Time News Bulletin. Ada Derana, 13 March 2020. Available from: https://www.youtube.com/watch?v=q-uYf RqbeSU\&t=496s. Accessed 20 April 2020.

9. Epidemiology Unit. Coronavirus disease 2019 (COVID-19) - Situation Report, 18 March 2020. Colombo: Epidemiology Unit, Ministry of Health, Nutrition and Indigenous Medicine, 2020. Available from: http://epid .gov.lk/web/images/ pdf/corona_virus_report/sitrep-sl-en-1803_10.pdf. Accessed 25 April 2020.

10. WHO. Coronavirus disease 2019, Situation Report-57. Geneva: World Health Organization, 2020. Available from: http://epid.gov.lk/web /images/pdf/corona_virus_report/sitrep-gl-en-1803_10.pdf. Accessed 20 April 2020. 